\title{
EVIDENCES OF CONTINENTAL GROUNDWATER INPUTS TO THE SHELF ZONE IN ALBARDÃO, RS, BRAZIL
}

\author{
Karina Kammer Attisano*; Luis Felipe Hax Niencheski; Idel Cristiana Bigliardi Milani; Caroline dos Santos \\ Machado; Márcio Raimundo Milani; Simoni Zarzur and Carlos Francisco Ferreira de Andrade \\ Fundação Universidade Federal de Rio Grande - FURG \\ Laboratório de Hidroquímica \\ (Caixa Postal 474, 96201-900 Rio Grande, RS, Brasil) \\ * Corresponding author: karina.attisano@gmail.com
}

\begin{abstract}
The southern coastal region of Brazil is highly productive and many of its oceanographic processes are still poorly understood due to a great number of forces, such as the continental input from the Plata River and Patos Lagoon, several distinct oceanic water masses, and a complex contribution from groundwater. The shelf near Albardão is highly rich in dissolved nutrients, particularly in the coastal zone. The narrow sandy barrier that separates the ocean from Mangueira Lagoon has led us to wonder about the possibility of groundwater, and if it might play a role in the productivity of the surrounding area. In order to test this hypothesis, nutrient data from Mirim and Mangueira Lagoons and from Albardão were collected during a rainy period. The present work shows the need to include groundwater transport from Mangueira Lagoon to the coastal zone as one of the main sources for the productivity in that region. However, for such phenomenon to be quantified and better understood, it becomes necessary to use natural isotopes as tracers of the underground input.
\end{abstract}

\section{RESUMO}

A região sul do Brasil é uma área altamente produtiva, cujos processos oceanográficos ainda são pouco compreendidos devido ao grande número de forçantes, tais como aportes continentais do Rio da Prata, Lagoa dos Patos, diferentes massas de água oceânicas e a complexa contribuição da água subterrânea. A plataforma da região do Albardão é extremamente rica em nutrientes dissolvidos, especialmente na zona costeira. O estreito cordão arenoso que separa a região do Albardão da Lagoa Mangueira levou-nos a questionar a possibilidade do transporte de água subterrânea e se este poderia contribuir de forma expressiva na produtividade dessa região. Para testar essa hipótese, associamos dados de nutrientes das Lagoas Mirim e Mangueira a dados inéditos da plataforma da região do Albardão, todos em período de alta precipitação. Este trabalho demonstra a necessidade de incluir o transporte de água subterrânea da Lagoa Mangueira para a região costeira, como uma das principais fontes para o aumento da produtividade da região. Entretanto, para quantificar e compreender melhor este fenômeno faz-se necessário o uso de isótopos naturais como traçadores desses aportes subterrâneos.

Descriptors: Groundwater; Continental transport; Nutrients; Submarine estuary; South Atlantic Ocean.

Descritores: Água subterrânea; Transporte continental; Nutrientes; Estuário subterrâneo; Oceano Atlântico Sul.

\section{INTRODUCTION}

Shelf waters in southern Brazil have been broadly characterized in terms of water masses and surface continental inputs (ROSSIWONGTSCHOWSKI and MADUREIRA, 2006), though their nutrient contents are still scarcely known. The area of Albardão located $120 \mathrm{~km}$ south of Rio Grande inlet (Fig. 1) is known to receive periodic inputs from Plata River and the Patos-Mirim lagoon complex that can elevate local nutrient concentrations. However, the proximity between the Albardão coastal area and Mangueira Lagoon has led us to wonder about the possibility of groundwater transport occurring from the lagoon to the ocean, and if this may impact the high productivity observed in the area.

Although the underground transport is not as evident as the surface one, element flows towards the ocean also take place through groundwater. This is a frequent phenomenon, particularly where the aquifer connects to surface seawaters through permeable sediments (BURNETT and DULAIOVA, 2003), which is the case at the southern Brazilian coastal plain. The transport of nutrients and substances through groundwater may alter the composition of 
surface waters, apparently without any anthropogenic influences (BURNETT et al., 2001). Work developed in the spit that separates Patos Lagoon from the Atlantic Ocean (WINDOM and NIENCHESKI, 2003; WINDOM et al., 2006) has provided evidence of continental transport through groundwater, in regard to the transport of nutrients and trace elements. It was demonstrated by those authors that underground flows may alter the chemical composition of waters in the adjacent continental shelf.

The study area consists of the MirimMangueira lagoon complex (Fig. 1).The main economic activity of that area is rice plantation, which demands the maintenance of water layers over the rice fields during the whole growth period (VILLANUEVA et al., 2000).

Water extraction for rice culture has altered the hydrologic regime in the region, including Mirim and Mangueira Lagoons and the Ecological Station of Taim (ESEC-Taim), a Federal Conservation Unit. These are interlinked systems, so that water removal for irrigation and the construction of irrigation systems (drainage channels, rising stations, dams) affect the whole system and may cause a reduction in the water volume needed for the maintenance of local ecosystems (BURGER, 2002). The system is more susceptible to hydrologic change during times of heightened evapotranspiration, as observed by Villanueva (2000) to occur during the months of October/November and February/March. During the dry season, water removal from the lagoons increases in order to supply the deficit in precipitation rates. This phase coincides with the growth phase in the plantations (Table 1), when the water level in rice farms must be gradually increased from 10 to $15 \mathrm{~cm}$, then kept at such level during growth development (ANA, 2001).

Mirim (230,000 ha) and Mangueira (80,200 ha) Lagoons supply most of the rice farms in the region with water. About $1.5 \mathrm{~L} \mathrm{~s}^{-1} \mathrm{ha}^{-1}$ of water from
Mirim Lagoon are used in the activity. On the other hand, water removal from Mangueira Lagoon must receive careful attention to the extracted volumes (BANZANEVE, pers. comm.), as it is the main supplying source for Taim wetlands (ESEC-Taim) must be dutifully protected, in view of its important ecological functions. Those lagoons ensure water availability during the whole irrigation period, leading many farmers to the wrong impression that the water sources in the region are inexhaustible (AMARAL and RIGHES, 2005). Such fact makes it yet more difficult to raise the local population's awareness.

The predominant winds come from the NESW (DHN, 1974), which coincide with the main axis of the lagoon bodies, they probably are the main forcing factors controlling both water level and circulation (GARCIA, 1998). Under NE winds, the waters in the lagoons are pushed southward, increasing local water and hydrostatic pressure levels in Mirim and Mangueira Lagoons. The opposite trend takes place when wind comes from the south. Therefore, it is presumed that Mangueira Lagoon plays an important role in supplying water to the aquifer, which advects into the oceanic coastal zone, by hydrostatic pressure difference. It is believed that such transport must be intensified in periods of high pluviometric indexes, when the hydrostatic pressure exerted on such waters is still greater. Corroborating this hypothesis are the high nutrient concentrations found in the coastal portion of the continental shelf near Albardão Lighthouse $\left(33.20^{\circ} \mathrm{S}\right.$ and $52.70^{\circ} \mathrm{W}$, Fig. 1). As this region is a singular place in regard to its high nutrient concentration, and the consequent high fish availability (SEELIGER et al., 2004), a multidisciplinary project is under way, whose aim is described by its own title: "Comparative assessment of the influence of oceanographic patterns on biological production at the continental shelf and slope in two southern Brazilian areas".

Table 1. Rice cultivation phases.

\begin{tabular}{lccccccccccc}
\hline \hline JUN & JUL & AUG & SEP & OCT & NOV & DEC & JAN & FEB & MAR & APR & MAY \\
\hline Soil preparation & & & & & & & & & \\
Flooding for seeding & & & & & & & & \\
Drainage/Germination & & & & & & & \\
&
\end{tabular}

Flooding for growth

Draimage

Harvest

Source: ANA (2001) and Villanueva (2000). 


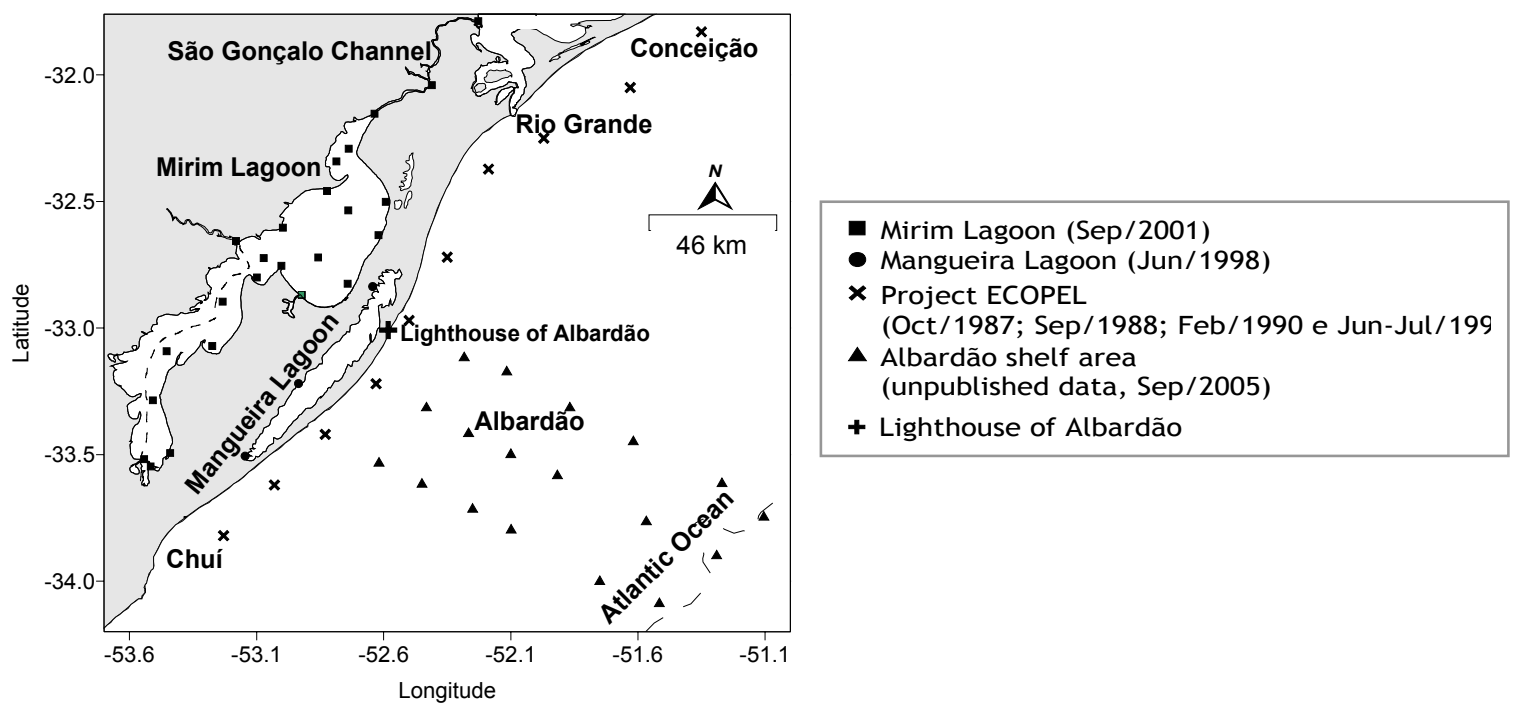

Fig. 1. Sampling stations location.

\section{Material ANd Methods}

Water samples were collected at four different locations (Fig. 1); two from both lagoon environments (Mirim and Mangueira Lagoons), and two from both oceanic environments (continental shelf and oceanic coastal zone). In Mirim and Mangueira Lagoons, due to their shallow depth, only surface samples were collected. The samples from the Albardão continental shelf used for this study were collected from a $5 \mathrm{~m}$ depth, thus called subsurface samples. For samples related to the South West Atlantic Ocean margin, the samples used were surface, subsurface and $10 \mathrm{~m}$ depth samples.

In Mirim Lagoon, 24 samples were collected along São Gonçalo Channel and the Brazilian portion of the lagoon (Fig. 1), on September $13^{\text {th }}$ and $17^{\text {th }}$, 2001.

In Mangueira Lagoon, only three sample collections were conducted, which allowed for the representation of the whole lagoon, as they were distributed to the northern, southern and middle portion of the lagoon (Fig. 1). Those samples were collected on June $23^{\text {rd }}, 1998$.

At the Albardão shelf zone, 18 samplings, held between September $6^{\text {th }}$ and $9^{\text {th }} 2005$, were distributed along three transects. The oceanographic stations nearer the continent were located approximately $30 \mathrm{~km}$ from the coast (Fig. 1).

The sampling periods for the lagoons and the continental shelf near Albardão presented winter features, and were related to the months of soil preparation for rice cultivation (Table 1). In this period, there is no use of lagoon waters for seeding flood. Such fact, associated to the high pluviometric rates, was responsible for the level increase in the lagoons, which may reach up to $4 \mathrm{~m}$ above the normal level (FRIEDRICH, 2004).

For the oceanic coastal environment, the 10 oceanographic stations distributed between Chuí $\left(33.82{ }^{\circ} \mathrm{S}\right)$ and Conceição $\left(31.83^{\circ} \mathrm{S}\right)$ Lighthouses were recovered from project ECOPEL (CIOTTI et al., 1995). This project held four oceanographic cruises, which allowed the four seasons to be characterized: spring (October 1987); winter (September 1988); summer (February 1990), and autumn (June/July 1991).

Samples were collected using $1.5 \mathrm{~L}$ VanDorn bottles (Mirim and Mangueira Lagoons) and 5.0 L Niskin bottles (shelf and oceanic coastal zone), then transferred to previously washed plastic bottles $(1 \mathrm{~L})$. Samples were further divided into three parts: the first to measurement of temperature, $\mathrm{pH}$, salinity, and conductivity; the second for dissolved oxygen analysis; and the third one for nutrient and suspended matter analysis. The samples were filtered immediately after each sampling, through a $0.45 \mu \mathrm{m}$ cellulose acetate filter, with the help of a vacuum pump. After filtration, samples destined to nitrite, nitrate, ammonium, phosphate, and silicate analyses were stored in polyethylene bottles, with chemicals added when needed, and then frozen pending later analysis, according to methodology described in Baumgarten et al. (1996). 


\section{Results and Discussions}

Lagoon and INNER SHELF Environment

In order to compare samplings held in different years, a brief meteorological study was performed at the distinct environments. Although the year 1998 presented a strong influence from the El Niño, they may be compared to samples from 2001 and 2005, as every period was also under high pluviometric rates and predominant $\mathrm{NE}$ winds (ESTAÇÃO METEOROLOGICA DA FURG FURG's Meteorological Station - online).

Below follows a discussion of phosphate and nitrogen, dissolved oxygen and oxygen saturation percentage, as well as total suspended matter.

Phosphate and Nitrogen Compounds

The phosphate and nitrogen concentrations in Mirim Lagoon and the shelf near Albardão showed values near those proposed by Baumgarten and Niencheski (1998) for a balanced environment. Except for the areas with greater anthropogenic influence, Mirim Lagoon presented slightly higher concentrations (FRIEDRICH, 2004). Mangueira Lagoon, on the other hand, presented higher concentrations than those predicted for a natural environment, for both phosphate and nitrogen compounds (Fig. 2).

A great portion of those increased concentrations must be associated with irrigated rice cultivation, characteristic in the region. Rio Grande do Sul state is the largest rice producer, with $26 \%$ of

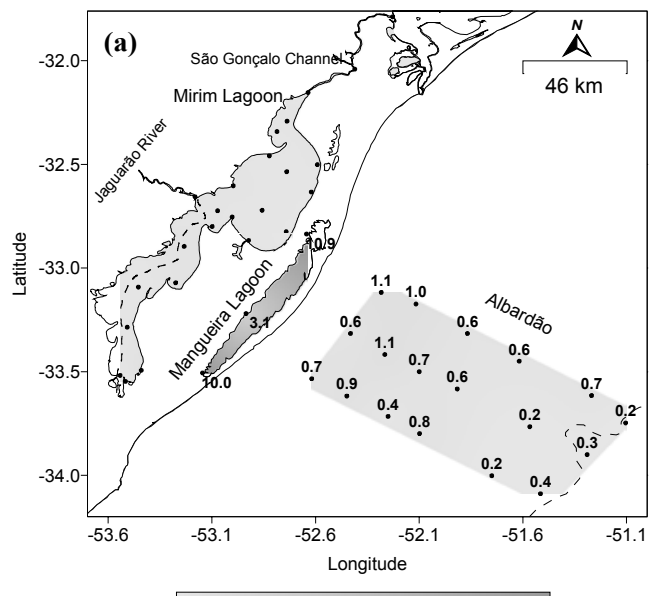

0.51 .52 .53 .54 .55 .56 .57 .58 .59 .5
Brazil's 3,616,200 hectares, and representing 45\% of the national yield (CONAB, 2000). The city of Santa Vitória do Palmar, where Mangueira Lagoon is located, uses about 90,000 hectares for rice growing (IRGA, 2001)

For the growing of irrigated rice, many agricultural inputs, as pesticides, and fertilizers are used (BUENO and LEMOS, 2006). The use of such compounds may cause serious environmental impacts, in that the water used for irrigation returns to the sources with no treatment whatsoever, by means of surface and groundwater. The recommendation for rice plantation in the state's land is up to $60 \mathrm{~kg} \mathrm{ha}^{-1}$ year ${ }^{-1}$ of $\mathrm{P}_{2} \mathrm{O}_{5}$ and $10 \mathrm{~kg} \mathrm{ha}^{-1}$ year $^{-1}$ of nitrogen in basic fertilization, though much higher amounts are actually used (at least $180 \mathrm{~kg} \mathrm{ha}^{-1}$ year $^{-1}$ of NPK fertilizer). Phosphorus loss by the draining of rice fields with organic soils may reach up to $30 \mathrm{~kg} \mathrm{ha}^{-1}$ year $^{-1}$ (IRGA, 2001).

The lost phosphorus is immediately absorbed by the soil's particles, which limits its presence in subsurface waters (water table). Due to being highly soluble, nitrogen may be found both in surface drainage waters and in subsurface ones. An excess of nutrients may be beneficial in return flows, if the water is used only for farm irrigation (ANA, 2001). Still, it may be harmful when discharging into a water course, leading to its eutrophication by the excessive increase in nutrient concentration, resulting in increased phytoplanktonic production and microbial activity. The biomass increase found for opportunistic species may lead to biodiversity reduction in the planktonic system, thus causing ecosystem imbalance (BURGER et al., 2002).

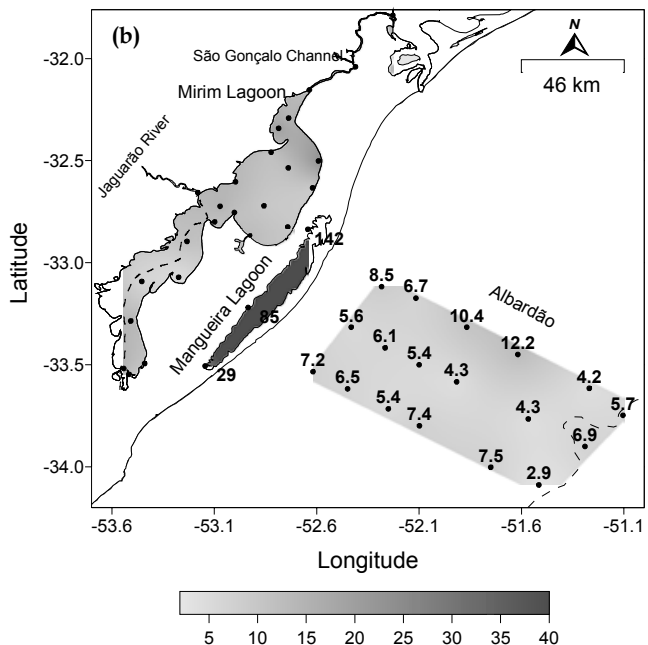

Fig. 2. Distribution of (a) phosphate and (b) nitrogen compounds $(\mu \mathrm{M})$ along the study area. 
The lost phosphorus is immediately absorbed by the soil's particles, which limits its presence in subsurface waters (water table). Due to being highly soluble, nitrogen may be found both in surface drainage waters and in subsurface ones. An excess of nutrients may be beneficial in return flows, if the water is used only for farm irrigation (ANA, 2001). Still, it may be harmful when discharging into a water course, leading to its eutrophication by the excessive increase in nutrient concentration, resulting in increased phytoplanktonic production and microbial activity. The biomass increase found for opportunistic species may lead to biodiversity reduction in the planktonic system, thus causing ecosystem imbalance (BURGER et al., 2002).

As of yet, the nutrient input implications are all but speculations, and there is no evidence showing the actual impact on adjacent aquatic environments (FRIEDRICH, 2004). Thus far, the system seems to be tolerating the excess of discharged nutrients, as Mirim Lagoon still presents nutrient concentrations within the stipulated range for a balanced environment, and the fish in Mangueira Lagoon are developing very well, reaching greater sizes than the usual (BRUSCH, 2005). However, this system needs monitoring, as those concentrations are not increasing in a natural way, but as a response to the human activities practiced in the region.

An important factor to be underlined is that there is a huge conflict between the economy and ecological conservation in the area between Mirim Lagoon and the Atlantic Ocean. In the same area

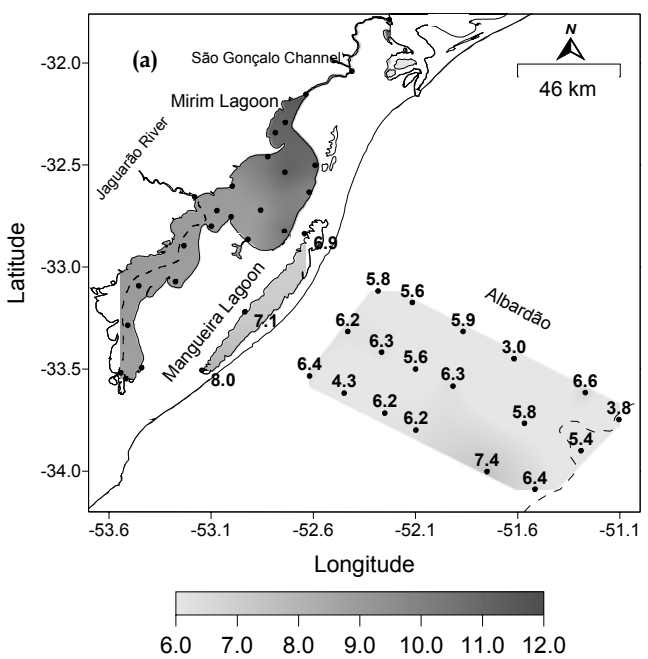

whose main income is linked to rice farming, there is the world known Taim wetland, located north of Mangueira Lagoon. Taim is basically formed by wetland, lagoon, dune, and beachfront ecosystems. This system has a key importance for ecological studies, mainly because Taim wetlands present one of the last remnants of such ecosystem type, which occupies $60 \%$ of the area within the Ecological Station (PELD, 2006).

\section{Dissolved Oxygen and Saturation Percentage}

Wind-driven water movement, along with the shallow depth in Mirim and Mangueira Lagoons, provide intense gas exchanges with the atmosphere, resulting in greater dissolved oxygen availability in the water. Still, in Mirim Lagoon, oxygen contents are higher, ranging from 8.49 to $11.85 \mathrm{mg} \mathrm{L}^{-1}$, possibly due to the shorter residence time and consequently to the greater renovation seen in those waters, as Mirim Lagoon receives several tributaries, both Brazilian and Uruguayan alike, the most important of which being Jaguarão River $\left(105 \mathrm{~m}^{3} \mathrm{~s}^{-1}\right.$; ANA, 2001). It is believed that the discharge from those tributaries into Mirim Lagoon increases water movement, making a greater amount of dissolved oxygen available, and thus keeping oxygen saturation at $100 \%$. Mangueira Lagoon, on the other hand, has no tributary at all. That is, all of its waters come from the aquifer and rainwater.

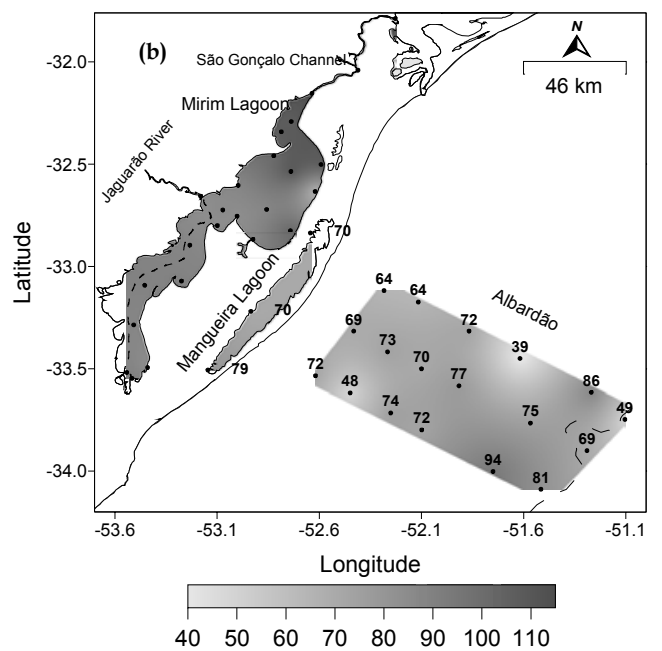

Fig. 3. Distribution of dissolved oxygen $\left(\mathrm{mg} \mathrm{L}^{-1}\right)$ and oxygen saturation (\%) along the study area. 
Undersaturation was found both in Mangueira Lagoon and in the shelf zone (Fig. 3). In Mangueira Lagoon, it may be a consequence of organic matter degradation, showing that the selfdepuration ability of the environment is not enough to take in the discharged load of organic matter (BAUMGARTEN and NIENCHESKI, 1998).

\section{Suspended Matter}

The suspended matter found in Mangueira Lagoon is associated to the extensive vegetation degradation in adjacent wetlands, especially macrophytes, the dominant vegetation in Taim wetlands. A modeling study by Paz (2003) concluded that vegetation and wind are the main forces driven wetland hydrodynamics, and that the vegetation's occurrence, characteristics, and its spatial distribution play a key role on a wetland's hydrodynamic behavior. Besides providing a strong additional resistance to drainage, both emerging or floating vegetation have a protective effect against wind action on the water surface, thus determining a longer drainage time for such waters. It may be seen in Figure 4 that the content of suspended matter reduces southwards in the lagoon, reaching values near $16 \mathrm{mg} \mathrm{L}^{-1}$.

It can be assumed that the increased organic matter contents in Mangueira Lagoon must be associated with farming activities and the intense degradation of the vegetation in adjacent wetlands, especially macrophytes, the dominant vegetation in Taim wetlands.

The resistance against the drainage of Mangueira Lagoon waters increases the residence time of organic compounds, thus intensifying the eutrophication process. With the increase in organic matter decomposition (mineralization) and the oxygen decrease, there is a predominance of reduced forms originated in the biological decomposition of protein organic matter, as well as the presence of phosphate in the water by the development of reducing conditions (BAUMGARTEN and NIENCHESKI, 1998). Also, the return - by surface and underground means - of phosphate and nitrogen-rich waters used for irrigation further increases the nutrient contents in this lagoon.

Some features of Mangueira Lagoon are more similar to offshore water than to coastal water. For example, the N/P ratio is under 16 , and alkalinity of its waters is around 1.5 meq $\mathrm{g} \mathrm{L}^{-1}$. Data from 1998 show a mean $\mathrm{pH}$ value equal to 8.00 , and research by ZERI Foundation (Zero Emissions Research and Initiatives) has found $\mathrm{pH}$ scores near 9.00, which is rare for a coastal lagoon without surface contact with the ocean. Such alkalinity and $\mathrm{pH}$ values are due to the existence of a shell deposit in the lagoon's bottom, as it was part of the ocean in the past - nearly 300,000 years (BRUSCH, 2005). We also believe that those characteristics may persist for a long time due to the ocean-lagoon interaction through groundwater, as the sand barrier that separates the lagoon from the ocean may behave as a "subterranean estuary" (WINDOM and NIENCHESKI, 2003), and the lagoon's level determines a greater or smaller saline intrusion into the sand strip.

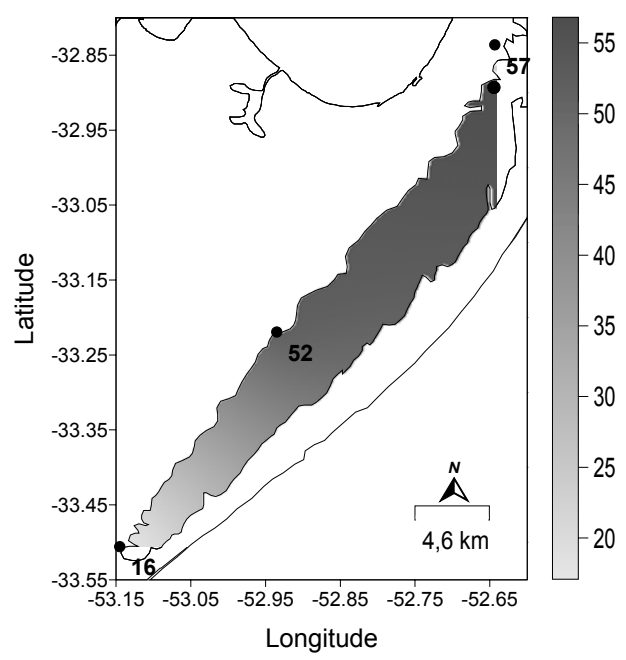

Fig. 4. Distribution of suspended matter in Mangueira Lagoon $\left(\mathrm{mg} \mathrm{L}^{-1}\right)$.

Coastal and Marine Environment

Offshore data obtained from one cruise (September 2005) reveal an important negative concentration gradient between the coast and the open sea. As such data come from just three transects at one specific region, previous data were recovered from Project ECOPEL, mainly those referring to stations nearer the coast, to identify the actual contribution of continental inputs from the southernmost end of Brazil (Chuí) up to Conceição Lighthouse, located north of the mouth of Patos Lagoon.

Satellite images reveal a persistent high chlorophyll signal at the confluence of the Brazil and Malvinas Currents (NIENCHESKI et al., 2007). The sources of macro and micro nutrients necessary to sustain such high productivity are poorly understood. Candidates include the convergence of the currents, the Rio de la Plata, and the Submarine Groundwater Discharge (SGD) from the coastal lagoons (Mangueira, Mirim and Patos) through a sandy barrier separating them form the ocean. To quantify SGD, transects across the shelf adjacent to Mangueira-Mirim lagoons have to be conducted, and radioisotopes should be used to constrain the residence time of shelf water. 
Before using this technique, a new interpretation of data obtained in several previous campaigns were applied based on concentration gradient along the coast. The only assumption required is that the concentration of the constituent in the freshwater and the oceanic endmembers are constant over the residence time of the coastal waters. For Rio Grande do Sul coastal water, this is assumed to be satisfied sufficiently to draw the conclusions presented in this paper. The use of previous data also brings the advantage of providing a four-season analysis to be made. Figure 5 shows the salinity distribution along this coast, where the mean is represented in this figure by a full line.

SPRING

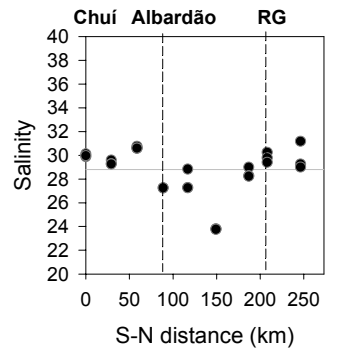

SUMMER

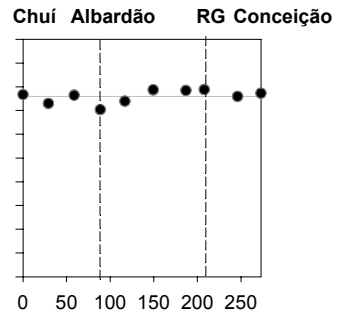

Silicate

The mean value of silicate concentrations for four selected regions located near the coast (Project ECOPEL) is presented in Table 2. The highest mean refers to the autumn and winter period, followed by spring and summer.

The mean values only indicate the periods with higher or lower contribution, but do not define the most important sources for each period. In order to determine the main sources at each time of the year, charts were built presenting the nutrient concentration versus the S-N distance from Chuí (zero $\mathrm{km}$ ) to Conceição $(273 \mathrm{~km})$. Silicate concentrations are represented in Figure 6.

AUTUMN

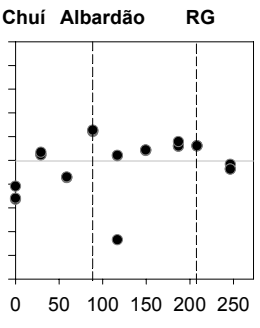

WINTER

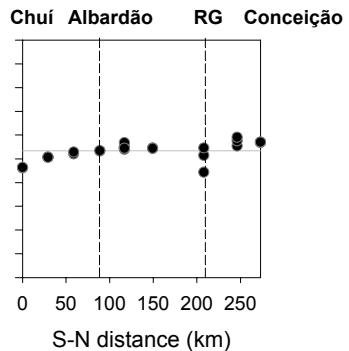

Fig. 5. Distribution of salinity (down to a $10 \mathrm{~m}$ depth) along the coast, from Chuí to Conceição.

Table 2. Silicate concentration mean $(\mu \mathrm{M})$ for the four seasons.

\begin{tabular}{|c|c|c|c|c|c|c|c|c|c|c|}
\hline \multirow[t]{2}{*}{ Region } & \multirow{2}{*}{$\begin{array}{c}\text { Latitude } \\
\left({ }^{\circ} \mathbf{S}\right)\end{array}$} & \multirow{2}{*}{$\begin{array}{c}\text { Longitude } \\
\left({ }^{\circ} \mathrm{W}\right)\end{array}$} & \multicolumn{2}{|c|}{ Spring } & \multicolumn{2}{|c|}{ Summer } & \multicolumn{2}{|c|}{ Autumn } & \multicolumn{2}{|c|}{ Winter } \\
\hline & & & $\bar{x}$ & STDEV & - & STDEV & $\bar{x}$ & STDEV & $\bar{x}$ & STDEV \\
\hline Chuí & 33.82 & 53.23 & 18.97 & 3.42 & 19.45 & 251 & 38.40 & 5.58 & 26.95 & 3.38 \\
\hline Albardão & 33.22 & 52.63 & 38.04 & 0 & 9.05 & 4.05 & 24.20 & 2.50 & 25.48 & 3.19 \\
\hline $\begin{array}{l}\text { Rio } \\
\text { Grande }\end{array}$ & 32.25 & 51.97 & 14.29 & 1.55 & 7.62 & 0.46 & 20.22 & 6.68 & 31.04 & 2.68 \\
\hline Conceição & 31.83 & 51.35 & - & & 7.75 & 0.24 & - & & 18.55 & 0.22 \\
\hline General* & & & 21.59 & 13.61 & 9.23 & 3.59 & 25.44 & 7.76 & 24.97 & 5.30 \\
\hline
\end{tabular}

General $^{*}=$ mean of all concentrations presented at each season in the whole study area.

SPRING

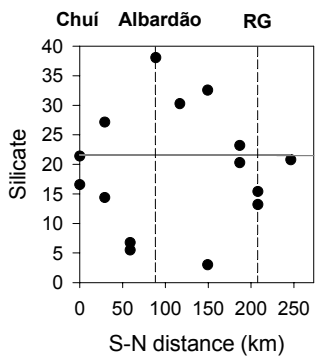

SUMMER

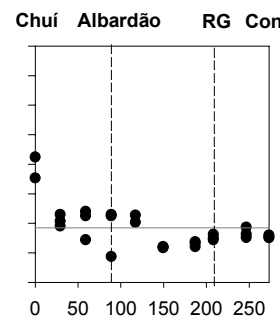

$\mathrm{S}-\mathrm{N}$ distance $(\mathrm{km})$
AUTUMN

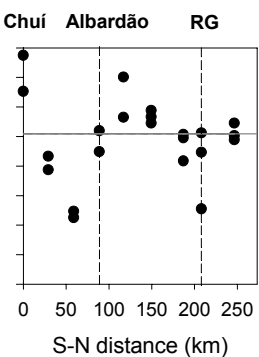

WINTER

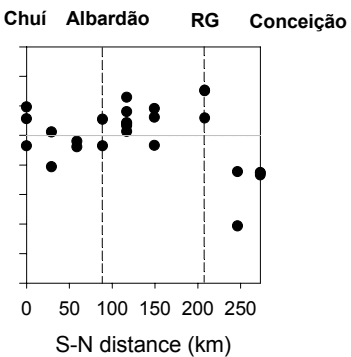

Fig. 6. Distribution of silicate concentrations as $\mu \mathrm{M}$ (down to a $10 \mathrm{~m}$ depth) along the coast, from Chuí to Conceição. 
Silicate may be a useful water mass tracer, especially for coastal water (NAGY and BLANCO, 1987; CIOTTI et al., 1995). The greatest continental input is found in autumn and winter periods. However, besides the land input, there is a seasonal concentration variation, which is intrinsic to its own biogeochemical cycle. It may be verified that continental inputs did not affect the seasonality of silicate's cycle, but enhanced it, as they were greater in periods of lower consumption (fall and winter), when silicate regeneration should be taking place, consequently increasing silicate bioavailability.

Water hydrochemistry in this region of the SW Atlantic Ocean is highly dependent on meteorological phenomena. For example, the periods with greater continental input (fall and winter) are related to the predominance of SW winds (GARCIA, 1998; CIOTTI et al., 1995). Such winds transport the waters of Plata River and Patos Lagoon northwards, providing a tendency of the study area to be dominated by continental waters from both waters bodies - at a greater scale by the Plata River, as its mean discharge is $23,300 \mathrm{~m}^{3} \mathrm{~s}^{-1}$ (PIOLA, 2002), almost 20 times greater than the mean discharge of Patos Lagoon, which ranges from 700 to $3,000 \mathrm{~m}^{3} \mathrm{~s}^{-1}$ (GARCIA, 1998). In spring and summer, dominant winds are from NE, which direct the waters southwards, helping the fresh water from Patos Lagoon to exit, and directing it southwards. The same occurs with the Plata River, whose low-salinity waters extend southwards along the Buenos Aires coast (PIOLA, 2002).

An analysis of Figure 6 shows that for any time of the year, the concentrations near Albardão Lighthouse are still high; in some instances, such as spring, even higher than the concentrations in stations located near the mouth of Patos Lagoon and Chuí (which represent the input of waters from the Plata). Such fact may indicate the existence of a silicate source other than the traditional ones (Plata River and Patos Lagoon) near Albardão. Those samplings were held during the spring of 1987, which was a year of El Niño predominance. Even with such phenomenon presenting moderate intensity, it was able to cause a positive rain anomaly in southern Brazil (CIOTTI et al., 1995). As already seen, the high pluviometric rates increase water levels in the lagoons and consequently the hydrostatic pressure, which favors groundwater transport through the sand barrier into the ocean. This fact corroborates the hypothesis that groundwater transport is taking place from Mangueira Lagoon towards the Atlantic Ocean. Also in spring, it may be seen that such transport was highly intense, as the mean silicate concentration near Albardão is almost twice the mean calculated for the whole spring of 1987 (Table 2).
In both summer and fall periods, higher silicate concentrations were found near Chuí, though in very different intensities (Fig. 6). Such fact is an evidence of the strong seasonal variability in continental waters from the Plata River. The seasonality of this river had already been noted in a study by Piola et al. (2000), which used oceanographic data from the continental shelf for a 30-year period.

In summer - the period in which the lowest continental contribution was seen -silicate contributions are distributed in a highly homogeneous way, except in the region that might be influenced by the surface waters of Plata River.

Autumn stands out as the period with the greatest continental influence, due to the increased silicate concentration mean presented along the whole period. Higher silicate concentrations were also seen near Chuí (more than $38 \mu \mathrm{M}$ ) whereas the silicate means near Albardão and Rio Grande were kept around $20 \mu \mathrm{M}$. Such fact indicates that the Plata River inputs are the highest for that time of the year. Though the silicate mean near Albardão is very near the mean found in Rio Grande and a little lower than the general mean for the season, groundwater influence in Albardão cannot be ruled out, due to the concentration decrease found between Chuí and Albardão. The increased silicate concentrations near Chuí gradually decrease northwards, reaching concentrations as low as $11.27 \mu \mathrm{M}$. They then increase again in the intermediate region between Albardão and Rio Grande, presenting higher concentrations near Albardão than Rio Grande (Fig. 6). The fact that the increased silicate concentrations are not found directly across from Albardão does not imply that they are not originated in the ground transport from Mangueira Lagoon, as in autumn the predominant winds are from SW, moving waters northwards.

In winter, in spite of the higher silicate concentrations found near Rio Grande right across from the mouth of Patos Lagoon, the concentrations found in Albardão presented highly similar values. The area near Conceição, on the other hand, presents much lower concentrations. Such findings from the three regions indicate that the plume formed by the discharge of Patos Lagoon cannot account for the high concentrations found in Albardão, as the plume is directed by the prevailing SW winds, and should have a greater influence over the region near Conceição and a lower effect over the region near Albardão. Still, Conceição is located $65 \mathrm{~km}$ north from the mouth of Patos Lagoon, whereas Albardão is located $120 \mathrm{~km}$ southwards. Therefore, were the plume influencing the silicate concentrations in Albardão, its influence should also be felt up north passing Conceição.

It may be seen that the concentrations from Albardão and those from Chuí are highly similar, and it could also be stated that the area by Albardão is 
influenced by the input from Plata River. Still by looking at the area between Chuí and Albardão, concentrations lower than those near Albardão can be found. That is another evidence that the increased silicate concentrations in Albardão are not only due to the influence of Patos Lagoon or Plata River, but also subjected to some "additional" source.

Still in regard to the winter, it is also seen that the concentrations between Rio Grande and Conceição areas decrease northwards, then increase very subtly near Conceição. Such fact points to the occurrence of groundwater transport from Patos Lagoon to the coastal oceanic region, as identified by Windom and Niencheski (2003). However, the available data reveal a higher underground transport efficiency in Albardão than in Conceição, possibly due to the width of the sand barrier and the low sediment permeability near Conceição (PEREIRA et al., 2005). The sand barrier separating Patos Lagoon from the Atlantic Ocean in Conceição is wider $(\sim 9 \mathrm{~km})$ than the barrier that separates Mangueira Lagoon from the ocean in Albardão $(\sim 5 \mathrm{~km})$. The permeability coefficient of the sediments was studied by Pereira et al. (2005), who considered the characteristics of the fluid and the medium, including porosity, size, shape, and arrangement. The authors found intermediate permeability for the whole Brazilian coast, except near Conceição Lighthouse and Concheiros (located from the middle towards the south of Mangueira Lagoon), where the lowest and the highest sediment permeability coefficients were found, respectively. Such factors, along with data obtained at stations located nearer the coast, are evidence of the higher

SPRING

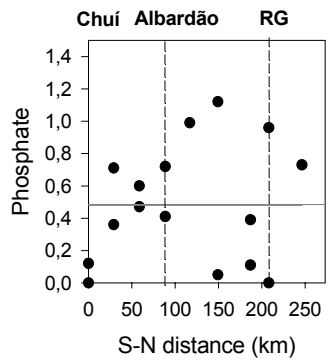

SUMMER

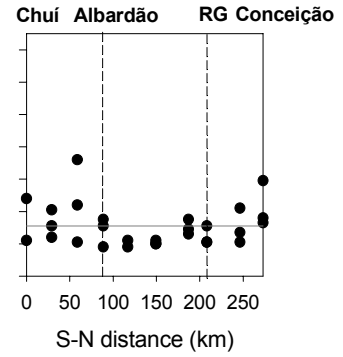

magnitude of the subterranean transport in Albardão relative to Conceição.

\section{Phosphate and Nitrogen Compounds}

The behavior of phosphate and nitrogen nutrients confirms the continental inputs pointed out by silicate data. The highest mean phosphate values were found in autumn and winter (Fig. 7), which represent the periods with the greatest continental input for the whole study area. The mean values between these periods present a very small variation $(\Delta=0.06)$, but even with virtually equal mean values, these two stations present dilution behavior in the opposite direction. In autumn, there is a northwards dilution of phosphate concentrations, and in winter the dilution follows the opposite direction, towards Chuí.

In autumn, lower concentrations are mainly found near Albardão and Rio Grande areas. Such consumption could be a result of an algae bloom, characteristic of the autumn period (ODEBRECHT and GARCIA, 1998).

In summer, phosphate and nitrogen nutrient concentrations were low in relation to the other periods of the year, and presented a homogeneous distribution due to the low continental input found for the period. Another reason must be phytoplankton consumption, because the surf zone has chlorophyll $a$ concentrations up to $1647 \mu \mathrm{g} \mathrm{L}^{-1}$ and brown colored patches of the surf-zone diatom Asterionellopsis glacialis, with cell concentrations up to $10^{8}$ cells $\mathrm{L}^{-1}$ (ODEBRECHT et al., 1995). Only near Chuí a small increase in concentrations is verified, probably related to the Plata River input.

Fig. 7. Distribution of phosphate concentrations as $\mu \mathrm{M}$ (down to a $10 \mathrm{~m}$ depth) along the coast, from Chuí towards Conceição. 
In spring, it is clearly possible to see the transport of phosphate along with groundwater from Mangueira Lagoon, as it results in higher phosphate concentrations near Albardão. Such increased phosphate concentrations may be explained by the buffer effect characteristic of phosphate that occurs when clay particles with a high amount of dissolved phosphate are found in saline water, which has a high ionic force and is rich in anions such as sulphates, chlorides, and carbonates. The interaction between fresh and saline waters induces the competition between those ions and the adsorbed phosphate for the adsorption sites on the particles' surface. Phosphate may be desorbed, thus increasing its concentration in the water. Therefore, an increase in dissolved phosphate may have occurred, compensating for the dilution caused by seawater, and keeping phosphate concentrations near $1 \mu \mathrm{M}$ (BAUMGARTEN and NIENCHESKI, 1998). Phosphate concentrations are also high across the mouth of Patos Lagoon. Such fact may be linked to the amount of excess soluble phosphate during fertilizer production being higher than that of nitrogen, which is frequent in the region (NIENCHESKI and WINDOM, 1994).

Still in spring, the concentrations were reduced towards Conceição. In winter, the opposite takes place, as the highest concentrations are found near Rio Grande, decreasing southwards. As already seen, the discharge from Patos Lagoon, which directly influences the area near Rio Grande, is indicated as the main factor responsible for the continental input in the winter period, resulting in an increase in nutrient concentrations at the place.

Both in summer and autumn, the distributions of nitrogen compound concentrations are highly homogenous (Fig. 8), with summer being the period presenting the lowest concentrations, and autumn presenting the highest concentrations for all seasons of the year. The high nitrogen compound concentrations found in autumn are consistent with our finding of high-intensity continental inputs from all three water bodies (Plata River, Patos, and Mangueira Lagoon)

Nitrate may be a good tracer for continental waters, as can be seen in Figure 9, always presenting high contents in regions that receive continental input, whether through surface (Chuí and Rio Grande) or underground transport (Albardão). The incoming nitrate is probably responsible for the new production in the region, which depends on nitrogen supplied from outside the euphotic zone, whose dominant source is nitrate (MANN and LAZIER, 1991).

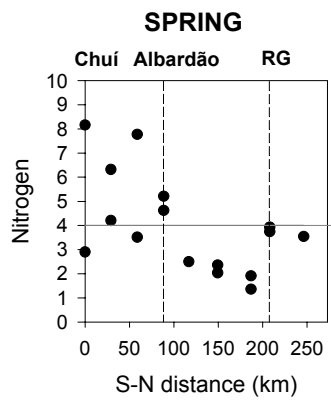

SUMMER

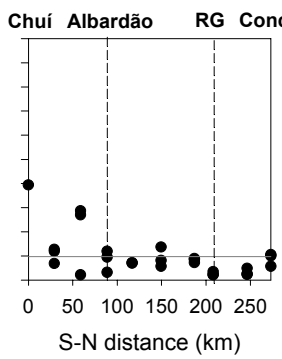

AUTUMN

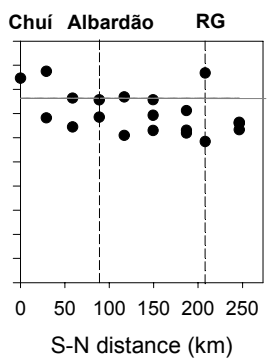

WINTER

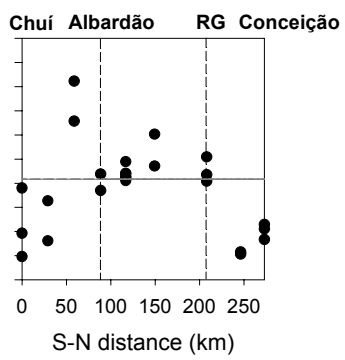

Fig. 8. Distribution of nitrogen compound concentrations as $\mu \mathrm{M}$ (down to a $10 \mathrm{~m}$ depth) along the coast, from Chuí towards Conceição.

SPRING



SUMMER

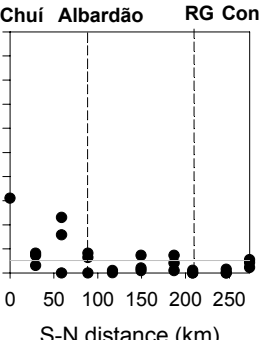

AUTUMN

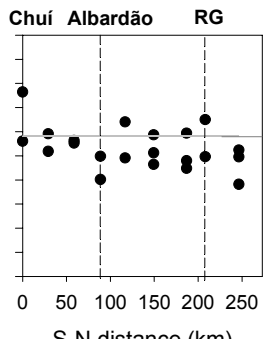

WINTER

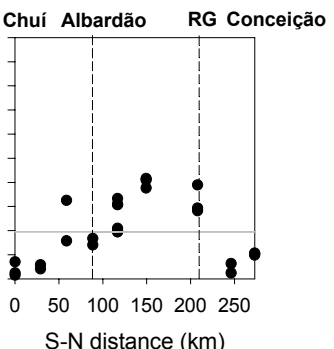

Fig. 9. Distribution of nitrate concentrations as $\mu \mathrm{M}$ (down to a $10 \mathrm{~m}$ depth) along the coast, from Chuí towards Conceição. 


\section{CONCLUSIONS}

The mean concentration values in Albardão were always very near or above the general nutrient mean, even when concentrations in Rio Grande or Chuí were high or low. It becomes increasingly clear that the area near Albardão is fed throughout the year by a source that is independent from the oscillations in discharge from Plata River and Patos Lagoon.

Therefore, this work assessed the need to include groundwater transport from Mangueira Lagoon into the coastal zone as one of the main sources for the productivity increase found in Albardão. In order to be able to quantify and to better understand such phenomenon in the southernmost coast of Rio Grande do Sul State, the quantification of groundwater transport is under way, by using natural isotopes as submarine groundwater discharge tracers.

\section{ACKNOWLEDGEMENTS}

The authors wish to thank Lucia Bohmer and Vanderlen Miranda for their assistance in field sampling and analysis. We also thank the students and staff of FURG/Laboratorio de Hidroquimica and the Captain (Mr. Homero) and crew of /R/V/ Atlantico do Sul. This work was partially supported by the National Research Council- CNPq (Grants 490126/2003-0; 301219/2003-6; 55.2715/2005-0), FAPERGS (Grant 0518017), and CAPES.

\section{REFERENCES}

AMARAL, L. G. H. do; RIGHES, A. A. Estruturas automáticas para controle de água nos canais em lavoura de arroz irrigado. Revta. Eng. Agríc., v. 25, n. 1, p. 272$281,2005$.

ANA. Relatório de visita de campo trecho paulista da Bacia do Paraíba do Sul, Cidades de Guaratinguetá e Taubaté. Rio de Janeiro: Fundação COPPETEC, Laboratório de Hidrologia e Estudos de Meio Ambiente da COPPE/UFRJ, Agência Nacional de Águas (ANA), 2001. Relatório Técnico.

BAUMGARTEN, M. G.; BARROS, S.; ROCHA, M. J.; NIENCHESKI, L. F. Manual de análises em Oceanografia Química. Rio Grande, 1996. 132 p.

BAUMGARTEN, M. G. Z.; NIENCHESKI, L. F. Avaliação da qualidade hidroquímica da área portuária da cidade de Rio Grande (RS) - Rio Grande. Rio Grande: Ed. Fundação Universidade Federal do Rio Grande, 1998.57 p.

BRUSCH, L. R. de F. Ações de avaliação, aproveitamento e geração de valor econômico aos ativos ecológicos brasileiros: a missão da Fundação ZERI Brasil. Zero Emissions Research Initiatives, Fundação ZERI Brasil, available online from http://www.zeri.org.br, acessed January, 2005
BUENO, A. da C.; LEMOS, C. A. S. Soil fertility of irrigated rice survey in Uruguaiana, RS. Revta. Fac. Zootec. Vet. Agro., v. 12, n. 1, p. 132-142, 2006.

BURGER, M. I.; MENEGUETI, J. O.; SILVA, M. S. da; SILVA, A. Q. da. Banhados e áreas úmidas costeiras. In: Workshop para avaliação e ações prioritárias para a conservação da biodiversidade das zonas costeira e marinha do Brasil. Relatório Técnico. Ministério do Meio Ambiente (MMA), Brasília, DF, 2002.

BURNETT, W. C. O.; DULAIOVA, H. Estimating the dynamics of groundwater input into the coastal zone via continuous Radon-222 measurements. J. environ. Radioactivity, v.69, n. 1-2, p. 21-35, 2003.

BURNETT, W.C.; TANIGUCHI, M.; OBERDORFER, J. Measurement and significance of the direct discharge of groundwater into the coastal zone. J. Sea Res., v. 46, n. 2, p. 109-116, 2001.

CIOTTI, A. M.; ODEBRECHT, C.; FILLMANN, G.; MÖLLER JR., O. O. Freshwater outflow and subtropical convergence influence on phytoplankton biomass on the southern Brazilian continental shelf. Cont. Shelf Res., v. 15, n. 14, p. 1737-1756, 1995.

CONAB - Companhia Nacional de Abastecimento. Estimativas de Safras. Indicadores da Agropecuária. Brasília, DF, v. 9, n. 2, p. 8 .

DHN - DIRETORIA DE HIDROGRAFIA E NAVEGAÇÃO - Atlas de cartas piloto do Oceano Atlântico: Trindade ao Rio da Prata. Rio de janeiro: 1974. 327 p.

ESTAÇÃO METEOROLÓGICA da FURG. Banco de Dados Meteorológicos da Estação Principal da Fundação Universidade de Rio Grande. Available online from: http//www.meteorologia.furg.br, accessed February, 2007.

FRIEDRICH, A. C. HIDROQUÍMICA DA LAGOA MIRIM-RS. 134 p. Dissertação (Mestrado). Fundação Universidade Federal do Rio Grande, Rio Grande, 2004.

GARCIA, C. A. E. Características Hidrográficas. In: SEELIGER, U.; ODEBRECHT, C.; CASTELlO, J. P. Os ecossistemas costeiro e marinho do extremo Sul do Brasil. Rio Grande: Ecoscientia, 1998. p 18-21.

IRGA. Arroz irrigado: recomendações técnicas da pesquisa para o sul do Brasil. Porto Alegre: Instituto Riograndense do Arroz, 2001. 128 p.

MANN, K. H.; LAZIER, J. R. N. Dynamics of marine ecossystems: biological-physical interacions in the oceans. Boston: Blackwell Scientific Publications, 1991. $466 \mathrm{p}$.

NAGY, G. J.; BLANCO, A. C. Balance de silicatos disueltos de superficie en el Rio de la Plata. In: CONGR. LATINOAM. DE CIÊNCIAS DEL MAR, COLACMAR 2, Perú, 1987. Vol. Único, Res. p. 132.

NIENCHESKI, L. F.; WINDOM, H. L. Nutrient flux and budget in Patos Lagoon estuary. The Science of the Environment, v. 149, p. 53-60, 1994.

NIENCHESKI, L. F.; WINDOM, H. L.; MOORE, W.S.; JAHNKE, R. Submarine groundwater discharge of nutrients to the ocean along a coastal lagoon barrier, Southern Brazil. Mar. Chem., v. 106, p. 546-561, 2007.

ODEBRECHT, C. L.; GARCIA, V. M. T. Composição taxonômica, densidade celular e diversidade. In: SEELIGER, U.; ODEBRECHT, C.; CASTELLO, J. P. Os ecossistemas costeiro e marinho do extremo Sul do Brasil. Rio Grande: Ecoscientia, 1998. p.117-122. 
ODEBRECHT, C. L.; RÖRIG, V. M. T.; ABREU, P. C. 1995. Shellfish mortality and a red tide event in southern Brazil. In: LASSUS, P.; ARZUL,G.; ERARD-LE D.; GENTIEN; MARCAILLOU, C. Harmful Marine Algal Blooms. Paris : Technique \& Documentation - Lavoisier Intercept, 1995. p. 213-218.

$\mathrm{PAZ}, \mathrm{A}$. Análise dos principais fatores intervenientes no comportamento hidrodinâmico do banhado do Taim (RS). 179 p. Dissertação (Mestrado), Instituto de Pesquisas Hidráulicas, Universidade Federal do Rio Grande do Sul, Porto Alegre, 2003.

PELD. Pesquisas Ecológicas de Longa Duração. Sistema hidrológico do Taim (sítio 7). Available online from http://www.peld.ufrgs.br, accessed January, 2007.

PEREIRA, P. S.; CALliARI, L. J.; GUEDES, R. M. C. Permeabilidade das praias arenosas do Rio Grande do Sul: reflexo da herança geológica e morfodinâmica de praias. In: CONGRESSO DA ASSOCIAÇÃO BRASILEIRA DE ESTUDOS DO QUATERNÁRIO, 10; CONGRESSO DA ABEQUA, 10., Guarapari, 2005. Vol. único.

PIOLA, A. R. El impacto del Plata sobre la plataforma continental. In: SCHNAK, E. J. (Ed.). TALLER EL NIÑO: sus impactos en el Plata y en la Región Pampeana. Com. Inv. Cient. de la prov. de Buenos Aires, Asoc. Bonaerense de Científicos, Fac. de Cs. Naturales y Museo de la Plata, La Plata, Argentina, 2002. Contribuciones. p. 19-22.
PIOLA, A. R.; CAMPOS, E. J.; MÖLLER JR., O.O.; CHARO, M.; MARTINEZ, C. The subtropical shelf front off eastern South America. J. geophysic. Res., v. 105(C3), p. 6565-6578, 2000.

ROSSI-WONGTSCHOWSKI, C. L. D. B.; MADUREIRA, L. S. P. O ambiente oceanográfico da plataforma continental e do talude na região sudeste-sul do Brasil. São Paulo: Editora da Universidade de São Paulo, 2006. 132 p.

SEELIGER, U.; CORDAZZO, C. E.; BARCELLOS, L. Areias do Albardão: Um guia ecológico ilustrado do litoral no extremo sul do Brasil, v. 1. Rio Grande: Editora Ecoscientia, 2004. 96 p.

VILLANUEVA, A. O. N.; MARQUES, D. da M.; TUCCI, C. E. M. The taim wetland conflict: a compromisse between environment conservation and irrigation. Water International, v. 25, n. 4, p. 610-616. 2000.

WINDOM, H. L.; NIENCHESKI, L. F. Biogeochemical processes in freshwater-seawater mixing zone in permeable sediments along the coast of Southern Brazil. Mar. Chem., v. 83, n. 3-4, p. 121-130, 2003.

WINDOM, H. L.; MOORE, W. S.; NIENCHESKI, L. F.; JAHNKE, R. A. Submarine groundwater discharge: A large, previously unrecognized source of dissolved iron to the South Atlantic Ocean. Mar. Chem., v. 102, n. 1, p. 252-256, 2006

(Manuscript received 23 February 2007; revised 28 August 2007; accepted 14 December 2007) 